\title{
A PROCESS-ORIENTED MODEL FOR SIMULATING AVALANGHE DANGER
}

\author{
By Arthur Judson, \\ (Rocky Mountain Forest and Range Experiment Station, 240 West Prospect Street, \\ Fort Collins, Colorado 80526, U.S.A.) \\ Charles F. Leaf, \\ (Consulting Engineer, $201 \frac{1}{2}$ Main Street, Sterling, Colorado 8075 I, U.S.A.) \\ and Glen E. Brink
}

(Rocky Mountain Forest and Range Experiment Station, 240 West Prospect Street, Fort Collins, Colorado 80526, U.S.A.)

\begin{abstract}
A simulation process model is developed for rating avalanche danger for twelve east-facing avalanche paths loaded by westerly winds. The model simulates layer age and densification, snow depth, snow transport and deposition, formation of melt crusts, snow temperatures, temperature gradient metamorphism, and avalanche danger on a $6 \mathrm{~h}$ basis. Conditioned on avalanches alone, the model predicted avalanche potential on $86 \%$ of the 175 avalanche days during an eight-year period. It indicated avalanche potential $50 \%$ of the time on non-avalanche days. A sensitivity analysis is under way to improve model performance, and simulation of danger from additional avalanche samples is planned.

RÉsumé. Un modèle de processus pour la simulation du danger d'avalanche. On développe un modèle de processus de simulation pour mesurer le danger d'avalanche sur 12 couloirs d'avalanches exposés à l'Est et chargés par les vents d'Ouest. Le modèle simule l'âge et le tassement des couches, la profondeur de la neige, les transports et dépôts de neige, la formation des croutes de fusion, les températures de la neige, la métamorphose de gradient, et les dangers d'avalanches sur la base d'un pas de temps de $6 \mathrm{~h}$. Conditionné pour l'avalanche seulement, le modèle a prévu une avalanches possible dans $86 \%$ des i 75 jours d'avalanches pendant une période de dix ans. Il a indiqué une possibilité d'avalanche $50 \%$ des jours sans avalanches. Une analyse de sensibilité est nécessaire pour améliorer la performance du modèle, et on a projeté de simuler le danger à partir de nouvelles observations d'avalanches.

Zusammenfassung. Ein prozessorientiertes Modell zur Simulation der Lawinengefahr. Zur Abschätzung der Lawinengefahr an 12 ostexponierten Lawinenbahnen, die ihre Schneeauflage von Westen her erhalten, wurde ein Prozessmodell entwickelt. Das Modell simuliert Schichtalter und -setzung, Tiefe, Transport und Ablagerung des Schnees, Bildung der Schmelzkruste, Schneetemperatur, Metamorphose infolge des Temperaturgradienten und Lawinengefahr im 6-Stunden-Rhythmus. Allein auf Lawinen abgestellt, sagte das Modell ein Lawinenpotential für $86 \%$ der I 75 Lawinentage in einem Zeitraum von ro Jahren richtig voraus. Es zeigte ein Lawinenpotential für 50\% der Zeit ohne Lawinenabgang an. Eine Empfindlichkeitsanalyse zur Verbesserung der Leistungsfähigkeit des Modells ist im Gange; Gefahrensimulation für weitere Lawinen ist geplant.
\end{abstract}

\section{INTRODUGTION}

Avalanche-warning programs in the United States and Europe are currently operated without the benefit of models. Forecasts are made by the judicious use of both experience and a basic knowledge of the physical processes affecting snow stability. This technique is flexible because it allows a synthesis of the important snow-structure and snow-texture variables together with pertinent weather data, avalanche response, and antecedent conditions. Heavy reliance is placed on the avalanche activity which obtains when the forecast is made, because this is one of the few definitive ways of determining stability: it also drastically reduces the number of false alarms. The main weaknesses of such programs are their heavy reliance on timely and accurate avalanche data, their high degree of subjectivity, the limited number of qualified personnel, and the immense task of remembering antecedent conditions for large, remote mountain areas. 
Future use of statistical and simulation process models for guidance will eventually alleviate some of these problems. Current research efforts are directed toward this goal, but progress has been slow due to the complexity of the problem. Perla (1970), Bois and Obled (1973), Judson and Erickson (1973), Bois and others ([1975]), Salway (unpublished), Föhn and others (1977), and Bovis (1977), made encouraging progress using techniques ranging from the use of scatter diagrams through discriminant function analysis to time-series modeling. All investigators had difficulty with important variables, including snow structure, snow texture, and wind. Snow-cover variables have always been difficult to analyze and are seldom available on a daily basis. Wind was not selected as a variable in most stepwise multiple regression techniques because it failed to discriminate between avalanche days and non-avalanche days. Frequently, snow available for transport is removed long before the wind drops its threshold speed. Use of a snow-transport model solves this problem. Because of difficulties associated with statistical treatment of snow and avalanche variables, we tried simulation modeling with a process-oriented model. The basic premise is that snow stability in avalanche starting zones is related to snow structure, texture, and loading rates, after minimum depth requirements are satisfied.

\section{Modeling TeGHNiQue}

Our simulation process model uses the approach developed by Leaf and Brink (1973[a], $\mathrm{r} 973[\mathrm{~b}])$ to forecast streamflow from Rocky Mountain alpine and subalpine zones. It uses the primary subroutines in the streamflow model. The streamflow model simulates: (I) winter snow accumulation, (2) the energy balance, (3) snow-pack conditions in terms of its energy level and free-water requirements, and (4) resultant snowmelt in time and space on all combinations of elevation, aspect, and slope. The snow-pack is assumed to behave as a dynamic heat reservoir, so input elements are expressed in units of heat. Precipitation events are added algebraically as caloric heat to develop the heat reservoir or snow-pack. Midpack temperatures are computed using unsteady heat-flow theory. Snowmelt is released only when the pack becomes isothermal and its free-water holding capacity is saturated.

The original streamflow model was modified and extended to simulate layer depth, age, densification, temperature gradient, temperature-gradient metamorphism, melt-crust formation, redistribution of snow by wind, loading rates, and avalanche danger. Six-hour indices of avalanche danger are based on snow structure, texture, and weighted average load values over the previous $72 \mathrm{~h}$. Load values in the previous $24 \mathrm{~h}$ receive full weight; lesser weights are assigned to older loads. The model handles wind (loading) from any direction.

The model simulates snow-pack stability on one or more avalanche units selected by aspect and terrain to represent avalanche paths characteristic of a given area. The avalanche unit (Fig. I) consists of an up-wind fetch, a down-wind deposition area (starting zone), and a down-wind zone representing the avalanche track. An idealized ground profile represents the major physical features of each unit. Specific numerical descriptors specify aspect, slope, and length of the fetch and deposition areas. The fetch is treated in three parts or cells to account for variations in the amount of snow trapped by vegetation and terrain irregularities along the fetch. The starting-zone area has a simplified triangular configuration with a maximum accumulation height $H$ which varies according to the slope angle $\phi$. Twenty-nine cells, each one meter long, are located in this area. Two cells maintained in the track give the unit a total of 34 cells. The 34 -cell total is caused by limitations in the computer memory, but programming techniques allow an extension of the starting zone beyond $29 \mathrm{~m}$ with little impact on the simulation. 


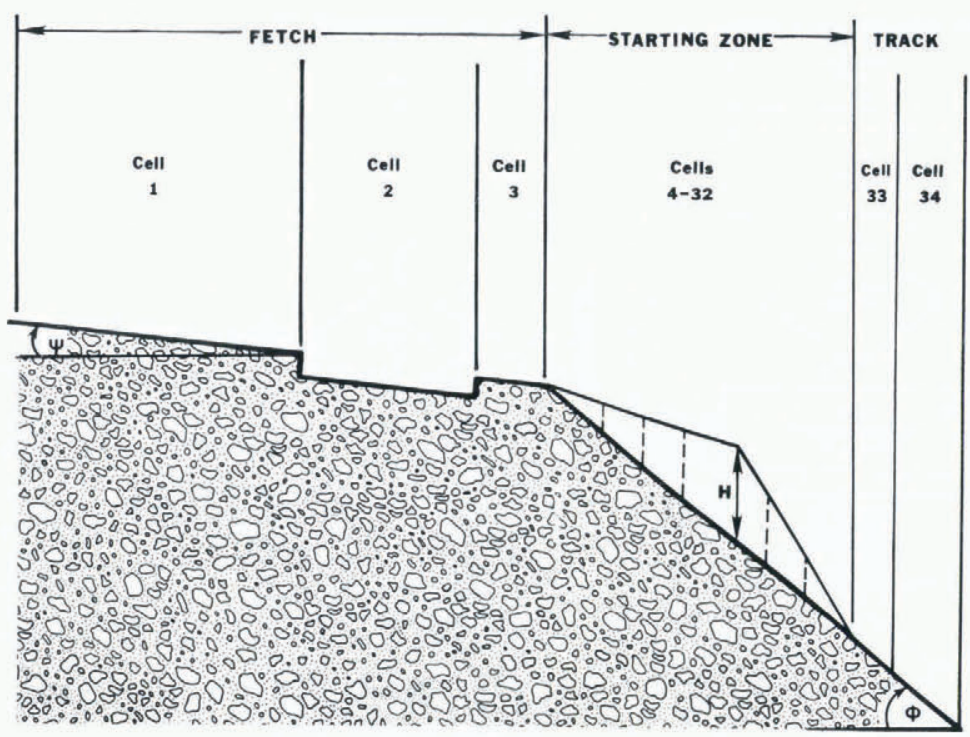

Fig. 1 . The idealized avalanche unit consists of an up-wind fetch, a down-wind deposition area (starting zone), and a down-wind zone representing snow conditions in the avalanche track. Thirty-four cells, representing various segments of the unit, are depicted. Cell 34 represents snow conditions in a level study plot.

\section{INPUT DATA}

Weather, snow, and avalanche data are from the Forest Service avalanche station at Berthoud Pass, Colorado. Temperature, precipitation, and snow depth were measured in a sheltered clearing at $3450 \mathrm{~m}$. Windspeed and direction come from instruments on a nearby ridge at $3620 \mathrm{~m}$. Avalanche data are from 12 paths situated within I $000 \mathrm{~m}$ (horizontal) of the weather sites. The 6 and $24 \mathrm{~h}$ inputs are:

\section{$6 \mathrm{~h}$}

temperature

precipitation

windspeed

wind direction
$24 \mathrm{~h}$

maximum/minimum temperature snow-fall precipitation incoming solar radiation observed avalanches

\section{Subroutines}

\section{General}

Figure 2 depicts the general flow of the model and displays the primary subroutines discussed. They deal with the seasonal snow-cover characteristic of the unit. Special subroutines for a permanent snow cover were developed for use on other units, but are beyond the scope of this presentation.

It should be noted that the $6 \mathrm{~h}$ avalanche danger ratings derived from the load analysis are based on both 6 and $24 \mathrm{~h}$ subroutines. For this reason, the avalanche danger rating subroutine will be discussed last.

\section{Layers}

To simulate the development of a layered snow cover, $6 \mathrm{~h}$ precipitation and snowtransport events are deposited in layers of water-equivalent with a minimum thickness of $5 \mathrm{~mm}$. Falling snow and windblown snow must be treated separately, because programming 


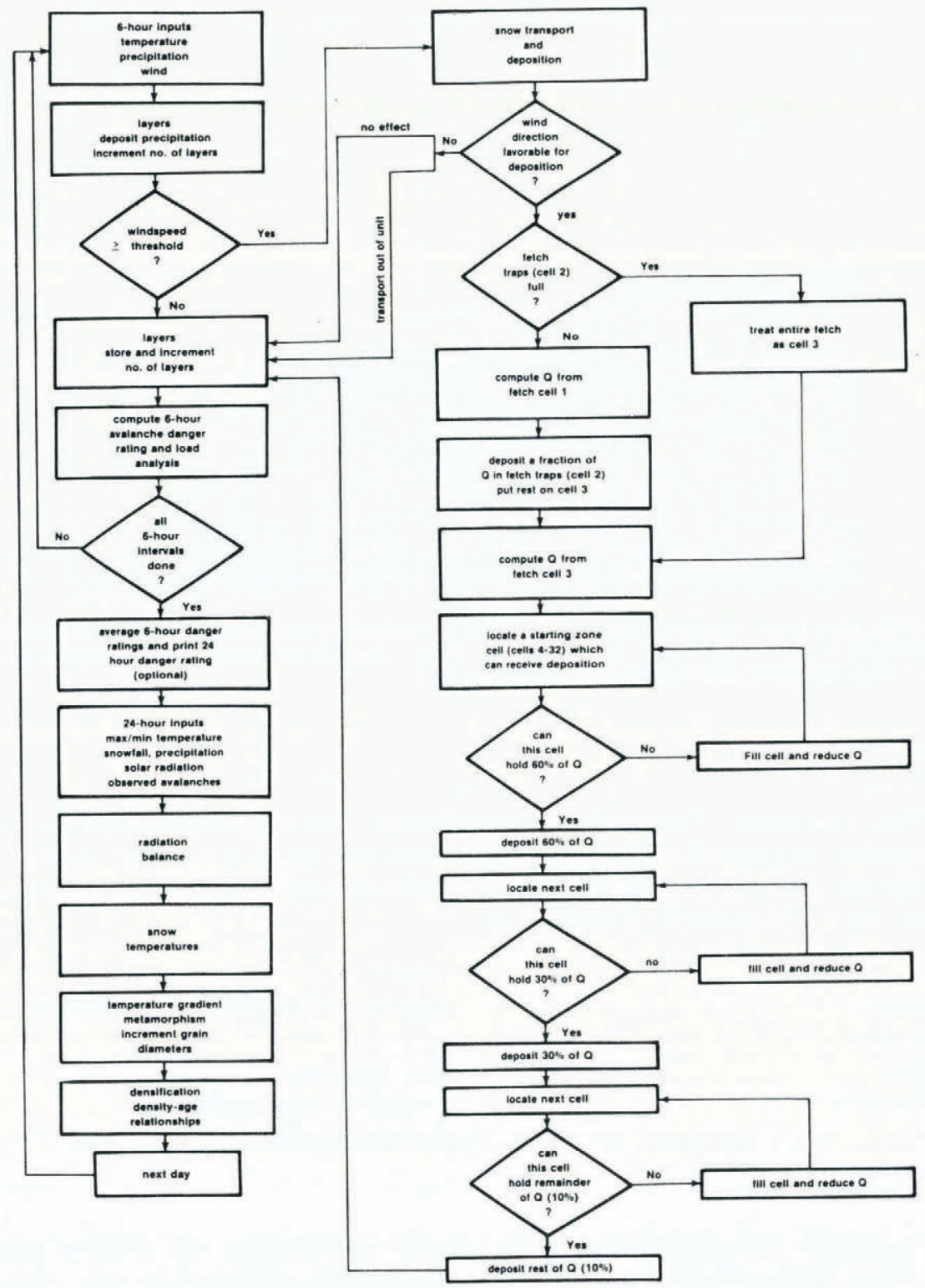

Fig. 2. General flow of the simulation model with primary inputs and process steps.

techniques do not allow simultaneous treatment of both events. Snow-fall is deposited at the end of each $6 \mathrm{~h}$ period. If the water-equivalent equals or exceeds $5 \mathrm{~mm}$, a layer is completed and a new layer will begin with the next event. When less than $5 \mathrm{~mm}$ falls, the layer fraction or sub-layer is stored until additional water-equivalent completes the layer. In the case of snow transport, layers are decremented and incremented on the fetch, and are incremented (occasionally decremented) in the starting zone. Layer age is stored for later use in computing avalanche danger, and in the densification subroutine which simulates snow depth. A maximum of 100 layers can form in every avalanche unit cell. 


\subsection{Snow transport}

\section{(a) Wind direction}

Wind direction is introduced when the speed exceeds the threshold value of $7.3 \mathrm{~m} / \mathrm{s}$ in the model. Wind direction is specified to (I) have no effect on the unit, (2) transport snow out of the unit, or (3) transport snow within the unit. In the first case, wind is not permitted to move snow in the unit due to obstructions in flow such as an arête or forest. In the second case, snow is transported out of the unit by cross-winds. There are two options in the third case. First, snow may be removed from one part of the fetch (cell I), deposited on another (cells 2 and 3 ), removed from cell 3 , and deposited in the starting zone. Second, snow can be removed from the starting zone and deposited on fetch cell 3 .

\section{(b) Theory}

Theory for this part of the model is based on the work of Budd (r966), Budd and others (1966), Schmidt (1972), Tabler and Schmidt (1973), and Tabler (1975). Basic equations are presented but not derived.

The volume of the snow transported from the fetch (cells I through 3 in Fig. I) is:

$$
Q=\frac{P_{\mathrm{r}} R_{\mu}}{2}\left[\mathrm{I}-(0 . \mathrm{I} 4)^{\left.R_{\mathrm{c}} / R_{\mu}\right]},\right.
$$

where $Q$ is the volume in units of water-equivalent per unit width perpendicular to the wind, $P_{\mathrm{r}}$ is the water-equivalent on the fetch available for relocation, in $\mathrm{mm}, R_{\mu}$ is the transport distance before an average sized particle evaporates, in $\mathrm{m}$, and $R_{\mathrm{c}}$ is the fetch length, in $\mathrm{m}$.

Water-equivalent available for relocation $\left(P_{\mathrm{r}}\right)$ from the fetch is given by the expression:

$$
P_{\mathrm{r}}=P-P_{\mathrm{s}},
$$

where $P$ is the water-equivalent of snow on the fetch, and $P_{\mathrm{s}}$ is the sum of the water-equivalent of snow trapped by vegetation, plus that which is stored by terrain irregularities, plus that which melts and evaporates. The amount of snow stored by vegetation and terrain irregularities is specified by field estimates.

There is a complex relationship between environmental conditions and the transport distance $R_{\mu}$, which is the distance an average-sized snow particle travels before it completely sublimates. It depends on wind-speed and sublimation processes. According to Tabler and Schmidt (1973):

$$
R_{\mu}=\frac{994.4\left(U_{\mathrm{I0}}-7.33\right)\left(0.02+0.0034 t^{0.4}\right)^{2}\left(T^{2}-8.2 T+254\right)}{\left[\left(\mathrm{I}+\frac{5}{U_{\mathrm{IO}}}\right)+37\left(0.02+0.0034^{0.4}\right)\right]\left[\left(\mathrm{I}-\frac{R H}{\mathrm{IOO}}\right)\right]\left[\left(\mathrm{I}+\frac{5}{U_{\mathrm{IO}}}\right)\right]} .
$$

Equation (3) is expressed in terms of $10 \mathrm{~m}$ wind-speed $U_{\mathrm{IO}}$ (in $\left.\mathrm{m} / \mathrm{s}\right)$, temperature $T$ (in ${ }^{\circ} \mathrm{C}$ ), relative humidity $R H$ (in per cent), and time $t$ (in hours) since the last snow-fall. Transported snow is available for deposition when $R_{\mu}>R_{\mathrm{c}}$ and when more snow is available for transport than required by the up-wind storage given in Equation (2).

The rate of snow transport $F$, in $\mathrm{g} / \mathrm{m} \mathrm{s}$, given by Budd and others (1966) is:

$$
\log F=\text { I.I } 8 \text { I } 2+0.0887 U_{\text {I0 }}
$$

where

$$
U_{\text {I0 }} \geqslant 7.33 \mathrm{~m} / \mathrm{s} \text {. }
$$

Equation (4) is programmed into the model with two modifications. First the ro m windspeed is modified by a simple trigonometric function so as to approximate changes in 
wind-speed along the fetch due to slope. Then, to restrict the flux when surface melt crusts are present $(F$ limits $Q)$ :

$$
\log F=\left(\text { I.181 } 2+0.0887 U_{10}\right) \exp (-\alpha),
$$

where $\alpha$ is an erodibility index based on crust thickness. Surface crusts reduce transport rates sharply until such time as the crusts themselves are eroded by strong winds.

\section{Snow deposition (wind-transported snow)}

Deposition areas in the avalanche unit include cells 2 and 3 on the fetch and cells 4 through 32 in the starting zone. Fetch cell 2 is $100 \mathrm{~m}$ long and fetch cell 3 is ro $\mathrm{m}$ long. For modeling purposes all cells are one meter wide and starting zone cells are one square meter in area, and have a finite volume obtained by specifying the maximum drift height above ground. Additionally, cells 1 to $3^{2}$ are given an initial holding capacity based on field estimates. No transport takes place from a cell that contains less snow than its holding capacity.

To approximate the deposition process in avalanche terrain, it is necessary to make gross assumptions based on a general knowledge of trapping efficiency. In general, trapping efficiency is a function of the angle subtended by the slopes of the erosion and deposition surfaces, the wind-speed over the area, and the amount of snow already in traps. These factors vary with each transport event. For our purposes, the following efficiency estimates were made:

$$
\begin{array}{ll}
\text { Cell I onto cell } 2 & 50 \% \\
\text { Cell I onto cell } 3 & 60 \% \\
\text { Cell } 3 \text { onto cells } 4-32 & 80 \% \text {. }
\end{array}
$$

On the relatively shallow-angled fetch surfaces, snow is allowed to accumulate in uniform layers, whereas loading in the steep starting zone is specified to occur in vertical, wedgeshaped layers. Snow transported from fetch cell $\mathrm{I}$ is available for deposition (after sublimation) on cell 2, and to a lesser extent on cell 3. Snow from cell 2 does not reach the starting zone cells until it is completely filled. When this occurs, the entire fetch is treated as cell 3 .

Snow is deposited into starting zone cells using a $6: 3:$ I ratio pattern (after Berg and Caine, unpublished). The total amount available for deposition $Q$ is deposited beginning with $60 \%$ in cell $4,30 \%$ in cell 5 , and $10 \%$ in cell 6 . If cell 4 will not hold $60 \%$ of $Q$, it is filled, $Q$ is reduced, and the $6: 3:$ I ratios are distributed into cells 5, 6, and 7 (see Fig. 2 for more detail). The sequence continues in this manner throughout the season. Discontinuities which occur in filled cells due to settlement and evapotranspiration are refilled by further deposition. Maximum cell heights can be exceeded briefly if snow falls on filled cells when wind-speeds are below the threshold value. The excess is sheared off, added to the total amount $Q$, and deposited with the next transport event.

\section{Radiation balance}

This subroutine is used without modification as it appears in the streamflow model described by Leaf and Brink (1973[a]). Incoming solar radiation is adjusted for slope and aspect according to tables published by Frank and Lee (1966). The long-wave components are derived using the average air temperature in the Stefan-Boltzmann function. Reflectivity of the snow-pack is changed according to the energy balance, precipitation, and time (U.S. Army, 1956).

\section{Snow temperatures}

The total heat energy input to the snow cover is indexed by the air temperature measured about one meter above the snow surface. For all practical purposes, studies have shown that temperature in this boundary layer approximates the integrated effects of wind, temperature 
and humidity of an air mass, and the radiation balance. The heat-flow equation solved by this method is given by Quick (1967) and Riley and others (1969):

$$
k_{\mathrm{s}} \frac{\partial^{2} T_{\mathrm{s}}}{\partial z^{2}}=c_{\mathrm{s}} \rho_{\mathrm{s}} \frac{\partial T_{\mathrm{s}}}{\partial t}
$$

where $k_{\mathrm{s}}$ is the thermal conductivity, $c_{\mathrm{s}}$ the specific heat capacity, $\rho_{\mathrm{s}}$ the snow density, $\mathcal{T}_{\mathrm{s}}$ the snow temperature, $z$ the depth below the snow surface, and $t$ is the time. Equation (6) can be rewritten as:

$$
\kappa_{v} \frac{\partial^{2} T_{\mathrm{s}}}{\partial z^{2}}=\frac{\partial T_{\mathrm{s}}}{\partial t}
$$

where $K_{v}$ is the thermal diffusivity.

Thermal diffusivity is assumed to vary with density as (Schwerdtfeger, I 963 ):

$$
\kappa_{v}=\frac{2 k_{\mathrm{i}}}{\left(3 \rho_{\mathrm{i}}-\rho_{\mathrm{s}}\right) c_{\mathrm{i}}},
$$

where $k_{\mathrm{i}}$ is the thermal conductivity of ice, $\rho_{\mathrm{i}}$ the density of ice, and $c_{\mathrm{i}}$ the specific heat capacity of ice.

Density is assumed to be constant across the pack for snow-temperature simulation, although it may vary with time. For our purposes, a weighted-average layer density, which is computed from the model, is used.

A finite-difference solution following the procedure outlined by Smith (1965), and Richmyer and Morton (1967) is obtained for Equation (7) using average air temperature, a preset ground temperature, and previous snow temperature at each node to simulate present snow temperatures. The number of simulated temperature nodes is dynamically proportional to snow depth with a spacing on the order of $15 \mathrm{~cm}$.

\section{Temperature-gradient metamorphism}

Development of temperature-gradient snow is simulated using the expression developed by Giddings and LaChapelle (1962):

$$
t=\frac{3 \cdot 7 \bar{D} \Pi_{\mathrm{a}}}{\Pi_{\mathrm{o}} \mathrm{d} T_{\mathrm{s}} / \mathrm{d} z}\left(\mathrm{I}+\frac{T_{\mathrm{s}}^{\frac{3}{2}}}{2 \mathrm{I} \cdot 5}\right),
$$

where $t$ is the formation time in days, $\bar{D}$ the final crystal diameter in $\mathrm{mm}, \Pi_{\mathrm{a}}$ the site specific atmospheric pressure in mbar, $\Pi_{0}$ the sea-level pressure in mbar, and $\mathrm{d} T_{\mathrm{s}} / \mathrm{d} z$ the snow temperature gradient in $\mathrm{deg} \mathrm{cm}^{-1}$.

The rate of formation is obtained by specifying initial and final crystal diameters $\bar{D}$ and solving for $t$. For modeling purposes we initialize $\bar{D}$ at $\mathrm{I} 50 \mu \mathrm{m}$ for wind-transported snow and $600 \mu \mathrm{m}$ for newly fallen snow. Growth is incremented according to Equation (9) using snow temperature and snow temperature gradients provided by Equation (7). When crystal diameters reach an arbitrary size of $0.7 \mathrm{~mm}$ they are designated as temperature-gradient (TG) snow. Thickness of TG layers is monitored every $24 \mathrm{~h}$. A high ratio of this layer thickness $T G$ to the total snow depth $H S$ increases avalanche danger as will be explained later. Routines for equi-temperature metamorphism were not developed.

\section{Layer densification}

The model uses five density functions to simulate snow depth and layer densification throughout the year. Density-age relationships were derived from long-term field data from Berthoud Pass, Colorado and Alta, Utah. The function chosen depends on time of year, snow structure, and load rate. The functions are: 


\begin{tabular}{cll} 
Number & \multicolumn{1}{c}{ Density } & \multicolumn{1}{c}{ Use } \\
I & 0.I I $x^{0.18}$ & standard \\
2 & 0.I $x^{0.18}+0.14$ & windblown snow \\
3 & $0.08 x^{0.31}$ & temperature-gradient snow \\
4 & $0.18 x^{0.19}$ & spring conditions \\
5 & 0.I $1 x^{0.18}+0.04$ & windblown snow with heavy snow-fall
\end{tabular}

where $x$ is the number of days. Function 4 is also used to account for rapid densification when young, low-density layers are loaded by heavy deposition.

\section{Avalanche danger}

\section{(a) Methodology}

The development of avalanche danger in the model closely parallels techniques used by operational forecasters except that data on current avalanche activity and the reaction of snow to destructive tests are not used. While this information is important in operational programs, we found no practical method of incorporating these inputs into the model due to problems of quantification and reliability on a short-term basis (i.e. every $6 \mathrm{~h}$ ).

When current avalanche data are unavailable the basic approach is to (I) determine if snow depth and stratigraphy satisfy initial conditions for avalanching, (2) evaluate existing snow stability on the basis of structure and load, and (3) estimate the effects of either a change in the present load or in the existing snow strength. Information for such determinations is available from the present model (i.e. snow depth, basic stratigraphy, and load in starting zone cells $4-32$ ). Initial conditions for avalanching in this unit are:

$$
\begin{aligned}
\text { snow depth } & \geqslant 0.2 \mathrm{~m}, \\
\text { layer age } & \geqslant 24 \mathrm{~h}, \\
\text { layer density } & \geqslant 100 \mathrm{~kg} \mathrm{~m}^{-3} .
\end{aligned}
$$

\section{(b) Theory}

Perla and Judson (unpublished) developed a theory for assigning weights to load increments with time. Given a continuous record of load as a function of time $L(t)$, the stability index $S$ should behave as:

$$
S(t)=\int_{0}^{t} M(t-\tau) \mathrm{d} L(\tau),
$$

where $M(t)$ is a positive monotonically decreasing function of time, and $M(0)=\mathrm{I}$. Equation (Io) states that the stability index $S(t)$ evaluated at time $t$ consists of a weighted sum of the load in the past interval $o \leqslant \tau \leqslant t$.

Discrete data points were used to approximate Equation (Io) as:

$$
S(t)=\Delta L_{0}+a_{1} \Delta L_{-1}+a_{2} \Delta L_{-2}+a_{3} \Delta L_{-3}+\ldots,
$$

where $\mathrm{I}>a_{1}>a_{2}>a_{3} \ldots$.

The coefficients $a_{1}, a_{2}, a_{3}, \ldots$ were determined from existing precipitation and avalancheoccurrence data using a discriminant-function analysis on data collected at several sites on the Forest Service's West-wide network (Judson, 1970). Results of this statistical work showed that loading events more than $72 \mathrm{~h}$ earlier had a negligible contribution to avalanching on any given day. The data agree with work done by Obled (1970) and Yefimov and Kozik (1974). Actual load weighting factors used in the model are: I for the first $24 \mathrm{~h}, 0.6$ for $25^{-28} \mathrm{~h}$, and 0.2 for $49-72 \mathrm{~h}$. In subroutine load analysis, the program scans load cells $4-32$ and selects the two cells containing the greatest weighted load over the previous $72 \mathrm{~h}$. A mean value for the two cells is then scaled, and this value gives the load factor $\Lambda$ for the avalanche unit every $6 \mathrm{~h}$. 
(c) Basal instability

The final step in developing avalanche danger for the model involves linking the load factor $\Lambda$ with structural weaknesses in the pack caused by the presence of temperaturegradient crystals. Examination of a large number of snow profiles taken in avalanche starting zones provided a means for incorporating this phenomenon into the model. The profiles were collected by project personnel and by members of the San Juan Avalanche Project (Armstrong and Ives, I976). The ratio of the depth $\mathrm{f} T G$ to the depth of the snow-pack HS was chosen to index this important snow-pack feature. The ratio is called the basal instability factor $B I F$. $B I F$ values range from I where $T G / H S=0.1$ to a maximum of 2. I following an S-shaped curve fitted by the expression:

$$
B I F=2.1 \mathrm{I} /[\mathrm{I}+3.73 \exp (-\mathrm{I} \mathrm{I} .44 T G / H S)],
$$

where $T G / H S>$ o. I. The model optionally limits $B I F$ to I once snow depth exceeds $2 \mathrm{~m}$.

\section{(d) Avalanche-danger ratings}

The avalanche-danger rating $A D R$ is the product $B I F \Lambda$ depicted in Figure 3 on a $24 \mathrm{~h}$ basis from December I 973 through February I974. ADR is set at zero until initial conditions with respect to snow depth, age, and density are satisfied. At this point a background $A D R$ of $\mathrm{o} . \mathrm{I}$ is assigned to account for minimal danger which persists through the winter. Six-hour $A D R$ s are computed using the current six-hour load factor $\Lambda$ and the previous day's BIF because layer thickness $T G$ comes from a $24 \mathrm{~h}$ subroutine.

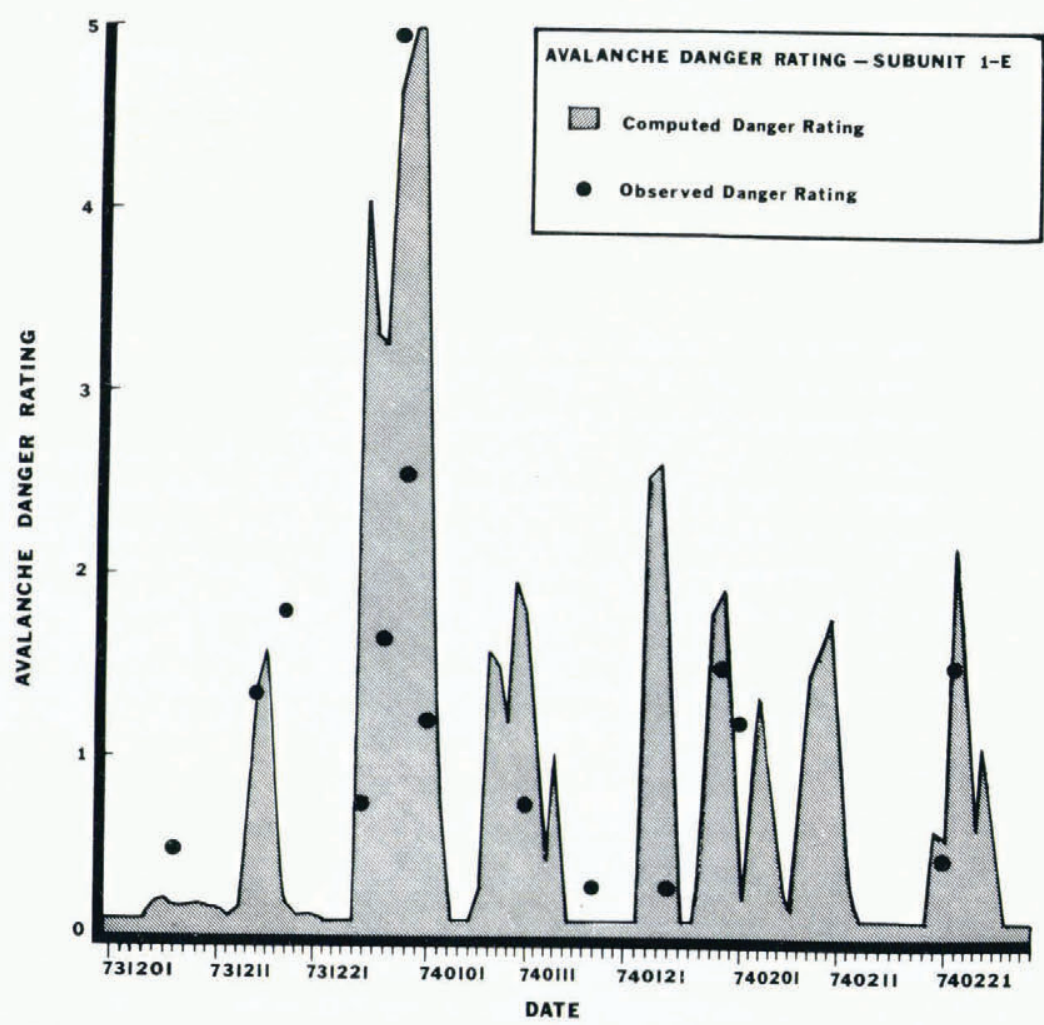

Fig. 3. Comparison of computed versus observed avalanche danger, December-February for winter 1973-74. 


\section{ObServed AVAlanche danger (obSERVed AVAlanches)}

Twelve east-facing avalanche paths are in this first unit. Five paths are uncontrolled, four receive light ski control, and the remaining three receive moderate to heavy control. Excellent weather and avalanche data are available from 1962-79. Observed avalanche danger in Figure 3 is a function of the number of avalanches, sizes, types, and avalanche-path constants. The path constant is a product computed as the inverse of the path frequency and its control intensity. For example, the smallest path constant of 0.2 was assigned to the path with the highest frequency and the heaviest control. The remaining path constants range from 0.3 to I.2. Maximum possible daily avalanche danger for the subunit is 63.6 , and the greatest observed one-day value was i 5.6 for the period. This formulation of the predictand allows use of natural and artificial avalanches, and accounts for the severity of avalanching by combining several aspects of the phenomena.

\section{RESULTS}

Baseline model runs were made for the eight winters, 1970-77. The model predicted avalanche potential on $86 \%$ of the 175 avalanche days during the initial test period. For our purposes, avalanche potential is defined as any computed avalanche-danger rating greater than the background $A D R$ of 0 . I. The model indicated avalanche potential $50 \%$ of the time on non-avalanche days, for an overall error rate of $45 \%$. A sensitivity analysis is currently under way to improve model performance and test the validity of the process steps in this prototype model. For the time being, initial results appear promising, and avalanche danger for the unit will be simulated on a real-time basis during the winter 1979-80. Model output will be available every $6 \mathrm{~h}$ in Colorado's avalanche-warning center for direct comparison with conventional techniques.

\section{Future WORK}

Considerable work remains in basic research and analysis of present model capability. Additional basic research is needed on threshold windspeeds, trapping efficiency, depositional mechanisms, and development of equi-temperature algorithms. Analysis of present model capability has just begun, using a fraction of the data available for determining snow stability. Some intriguing options include assessment of the load factor $\Lambda$ over more than two cells, introduction of subroutine AVALANCHE for ADR adjustments, use of additional snow-cover variables, and adjusting numerous parameters present in the prototype model.

Upon completion of the analysis for this avalanche unit, additional units will be added to represent avalanche danger for an entire region. Further analysis will entail a comparison of simulated responses of the physical processes affecting snow stability with avalanche data from all representative units. If this work produces satisfactory results the model will be extended to other avalanche areas in the west.

\section{Acknowledgement}

The authors express sincere thanks to R. A. Schmidt of the Fort Collins Mountain Snow and Avalanche Project for his interest and technical support in the development of the snow transport and deposition sections of this paper. 


\section{REFERENGES}

Armstrong, R. L., and Ives, J. D., ed. 1976. Avalanche release and snow characteristics, San Juan Mountains, Colorado. University of Colorado. Institute of Arctic and Alpine Research. Occasional Paper No. 19.

Berg, N., and Caine, N. Unpublished. Prediction of natural snowdrift accumulation in alpine areas. [Ph.D. thesis, University of Colorado, 1977.]

Bois, P., and Obled, C. 1973. Vers un système opérationnel de prévision numérique des avalanches à partir de méthodes statistiques. Hydrological Sciences Bulletin, Vol. 18, No. 4, p. 419-29.

Bois, P., and others. [1 1975.] Multivariate data analysis as a tool for day-by-day avalanche forecast, [by] P. Bois, C. Obled, and W. Good. [Union Géodésique et Géophysique Internationale. Association Internationale des Sciences Hydrologiques. Commission des Neiges et Glaces.] Symposium. Mécanique de la neige. Actes du colloque de Grindelwald, avril 1974, p. 391-403. (IAHS-AISH Publication No. 1 14.)

Bovis, M. J. 1977. Statistical forecasting of snow avalanches, San Juan Mountains, southern Colorado, U.S.A. Fournal of Glaciology, Vol. 18, No. 78, p. 87-99.

Budd, W. F. 1966. The drifting of non-uniform snow particles. (In Rubin, M. J., ed. Studies in Antarctic meteorology. Washington, D.C., American Geophysical Union, p. 59-70. (Antarctic Research Series, Vol. 9.))

Budd, W. F., and others. I966. The Byrd snow drift project: outline and basic results, by W. F. Budd, R. J. Dingle, and U. Radok. (In Rubin, M. J., ed. Studies in Antarctic meteorology. Washington, D.C., American Geophysical Union, p. 71-134. (Antarctic Research Series, Vol. 9.))

Föhn, P., and others. 1977. Evaluation and comparison of statistical and conventional methods of forecasting avalanche hazard, by P. Föhn, W. Good, P. Bois, and C. Obled. Fournal of Glaciology, Vol. 19, No. 81, p. $375-87$.

Frank, F. C., and Lee, R. 1966. Potential solar beam irradiation on slopes: tables for $30^{\circ}$ to $50^{\circ}$ latitude. U.S. Dept. of Agriculture. Forest Service. Research Paper RM-18.

Giddings, J. C., and LaChapelle, E. R. 1962. The formation rate of depth hoar. Journal of Geophysical Research, Vol. 67 , No. 6, p. $2377-83$.

Judson, A. 1970. A pilot study of weather, snow, and avalanche reporting for the western United States. Canada. National Research Council. Associate Committee on Geotechnical Research. Technical Memorandum No. 98, p. 123-34.

Judson, A., and Erickson, B. J. 1973. Predicting avalanche intensity from weather data: a statistical analysis. U.S. Dept. of Agriculture. Forest Service. Research Paper RM-I 1 2. [Rocky Mountain Forest and Range Experiment Station, Fort Collins, Colorado.]

Leaf, C. F., and Brink, G. E. I973[a]. Computer simulation of snowmelt with a Colorado subalpine watershed. U.S. Dept. of Agriculture. Forest Service. Research Paper RM-99.

Leaf, C. F., and Brink, G. E. 1973[b]. Hydrologic simulation model of Colorado subalpine forest. U.S. Dept. of Agriculture. Forest Service. Research Paper RM-107.

Obled, C. ' 1970. Vers une prévision numérique des risques d'avalanches. Grenoble, Comité d'Études et de Documentation Nivologiques et Glaciaires. ([Contract report] D.G.R.S.T. 69/02/094.)

Perla, R. I. 1970. On contributory factors in avalanche hazard evaluation. Canadian Geotechnical Journal, Vol. 7, No. 4, p. 414-19.

Perla, R. I., and Judson, A. Unpublished. Fading memory analysis of avalanche contributory factors. [Study plan, U.S. Dept. of Agriculture, Forest Service, Rocky Mountain Forest and Range Experiment Station, Fort Collins, Colorado, 1972.]

Quick, M. C. 1967. A comparison of measured and theoretical snowpack temperatures. Fournal of Hydrology,
Vol. 5, No. 1, p. I-20. Vol. 5, No. I, p. I-20.

Richmyer, R. D., and Morton, K. W. 1967. Difference methods for initial-value problems. Second edition. New York, John Wiley and Sons, Inc.

Riley, J. P., and others. 1969. Snowmelt simulations, by J. P. Riley, D. C. Chadwick, and K. D. Eggleston. Proceedings of the Western Snow Conference, 37th annual meeting, p. 49-56.

Salway, A. A. Unpublished. Statistical estimation and prediction of avalanche activity from meteorological data for the Rogers Pass area of British Columbia. [Ph.D. thesis, University of British Columbia, 1976.]

Schmidt, R. A. 1972. Sublimation of wind-transported snow-a model. U.S. Dept. of Agriculture. Forest Service. Research Paper RM-go.

Schwerdtfeger, P. 1963 . Theoretical derivation of the thermal conductivity and diffusivity of snow. Union Géodésique et Géophysique Internationale. Association Internationale d'Hydrologie Scientifique. Assemblée générale de Berkeley, 19-8-3I-8 1963. Commission des. Neiges et des Glaces, p. 75-81. (Publication No. 61 de 1'Association Internationale d'Hydrologie Scientifique.)

Smith, G. D. 1965. Numerical solution of partial differential equations. New York, Oxford University Press.

Tabler, R. D. 1975. Estimating the transport and evaporation of blowing snow. Great Plains Agriculture Council. Research Committee. Publication No. 73, p. 85-104.

Tabler, R. D., and Schmidt, R. A. 1973. Weather conditions that determine snow transport distances at a site in Wyoming. (In [International Hydrological Decade.] The role of snow and ice in hydrology. Proceedings of the Banff symposia, September 1972. Paris, UNESCO; Geneva, WMO; Budapest, IAHS, Vol. 1, p. I 18-26. (Publication No. I07 de l'Association Internationale d'Hydrologie Scientifique.)) U.S. Army. 1956. Snow hydrology. Summary report of the snow investigations. Portland, Oregon, Corps of Engineers.
North Pacific Division.

Yefimov, M. K., and Kozik, Ye. M. 1974. Svyaz' nekotorykh meteorologicheskikh elementov so skhodom lavin $\mathrm{v}$ basseyne r. Dukant (Zapadnyy Tyan'-shan) [Relation of some meteorological elements to avalanching in the Dukant river basin (Western T'ien-shan]. Trudy Sredneaziatskogo Regional'nogo Nauchno-Issledovatel'skogo Gidrometeorologicheskogo Instituta, Vyp. $15(96)$, p. $144-48$. 